\title{
The "Commodification" of Knowledge in the Global Information Society
}

\section{Peter Fleissner}

Technische Universität Wien, Wiedner Hauptstrasse 19/45, A-1040 Viena (Austria) E-mail: fleissner@arrakis.es

\begin{abstract}
With the increasing division of labour and the emergence of markets, useful things have started to become sold and bought. They began a new career as commodities. Since Aristotle the dialectic face of commodities, later on in detail elaborated by Karl Marx, is well known, they carry value in use and value in exchange. Nowadays, where we understand the economy as a social construction and are aware of the relativity of value given to objects, we are still confronted with the same distinction and also with the transition of objects into commodities. The commodification process has not come to an end yet.

The paper gives an overview on the processes of commodification and de-commodification of goods and services as a background for analysing developments in the emerging information society on a global scale.

Possible strategies on how to go on from now are presented, among them the struggle and on-going resistance of the European Parliament on the one hand, against the European Commission and the European Patent Office on the other, also the movements of open source/free software and the ideas of copyleft to create new rules for information goods.
\end{abstract}

Keywords: Commodification, Information Goods, Information Society

T he emergence of the global information society is a great challenge for social scientists and, last not least, also for Marxian scholars. After the implosion of "real socialism" in the Soviet Union and many other socialist allies and the parallel expansion of neo liberal regulation in international trade new questions are put on their agenda. What are the essential changes in the productive forces? Can one already identify a new quality of relations of production? Can there already be seen germs of new developments which might give hope for a better future? But there are even more profound doubts in place: Can the theoretical position of the classical Marxian thinkers still help us to get a deeper understanding of contemporary society? Is the terminology of classical Marxism still adequate for the analysis of contemporary capitalism? Do we have to modify the concepts? And in case we do; in which direction? And even more important: What should the essential economical, political, social and cultural features of a new society be, may it be called socialism or not? What will be its shape? Will it be that attractive to a growing majority of people that they will give up their actual way of life in exchange for an uncertain future, taking into account the probably high costs of the transition? Who is the revolutionary subject not only heavily interested but also able to transforming the ideas of a better society into practice? Or can we come along without identifying special classes or social strata?

There are several strategies at hand how to cope with such a situation. The first would be to give up and to do without any theoretical understanding of the world, to make peace with and to settle in capitalism. But this would not bring us in a better situation: the particular interests of a few would go on to deteriorate the life on our planet.

Another way would be to go on with the classical tools of Marxism, more and more 
desperately keeping up outdated concepts, following the revolutionary rituals of the past and accusing the one or the other of the socialist political leaders of having betrayed their citizens. In Europe such people are forming political sects who tend to split themselves again and again, condemning themselves to insignificance.

A more difficult but also more risky option is to go back to the roots and to have a fresh look at old concepts and theories, keeping the useful ones, and, if necessary, developing new and more adequate ones in the face of actual developments in society and in particular in the social-scientific environment.

In this paper the third option is chosen. I try to confront classical terms of political economics with contemporary developments, identifying new features of our societal reality, and to look for the shadows the future casts on the present.

\section{Commodification Processes}

Let us start elementarily with the notion of "useful things". Useful things have many attributes and can therefore be used in many ways - more or less independent of the social structure they are in. The usefulness of a thing makes it a use-value, because by its intrinsic characteristics it can satisfy some human need, either physical or imaginary. Although elementary, the concept of a useful thing is not trivial, because the notion of usefulness is rather tricky. The complex cobweb of the respective society is reflected in this notion. What is useful in one society can become completely useless in another one or vice versa, therefore even a use-value does not represent an invariant over time, as I will illustrate below. Marx has virtuously reflected this feature in a footnote of the "Grundrisse" (Outlines of the Critique of Political Economy):

"Is not value to be conceived as the unity of use value and exchange value? In and for itself, is value as such the general form, in opposition to use value and exchange value as particular forms of it? Does this have significance in economics? Use value presupposed even in simple exchange or barter. But here, where exchange takes place only for the reciprocal use of the commodity, the use value, i.e. the content, the natural particularity of the commodity has as such no standing as an economic form. Its form, rather, is exchange value. The content apart from this form is irrelevant; is not a content of the relation as a social relation. But does this content as such not develop into a system of needs and production? Does not use value as such enter into the form itself, as a determinant of the form itself, e.g. in the relation of capital and labour? the different forms of labour?-agriculture, industry etc.-ground rent?-effect of the seasons on raw product prices? etc. If only exchange value as such plays a role in economics, then how could elements later enter which relate purely to use value, such as, right away, in the case of capital as raw material etc.? How is it that the physical composition of the soil suddenly drops out of the sky in Ricardo? [Ed: for Ricardo's discussion of the effects of difficulties of cultivation on rent, see On the Principles of Political Economy, pp 55-75.] The word Ware [commodity] (German Güter [goods] perhaps as denrée [good] as distinct from marchandise [commodity]?) contains the connection. The price appears as a merely formal aspect in it. This is not in the slightest contradicted by the fact that exchange value is the predominant aspect. But of course use does not come to a halt because it is determined only by exchange; although of course it obtains its direction thereby. In any case, this is to be examined with exactitude in the examination of value, and not, as Ricardo does, to be entirely abstracted from, nor like the dull Say, who puffs himself up with the mere presupposition of the word 'utility'." (Marx, 1973, footnotes) $)^{1}$

With the increasing division of labour and the emergence of markets useful things have

\footnotetext{
${ }^{1}$ I am grateful to Dieter Haustein for this hint. [Online version]

<http://www.marxists.org/archive/marx/works/1857/grundr isse/f239-289.htm > [consulted in 03/04/2010]
} 
started to become sold and bought. They began a new career as commodities. Already Aristotle stated the twofold use of every object -which marks the definition of a commodity up to now:

"The one is peculiar to the object as such, the other is not, as a sandal which may be worn, and is also exchangeable. Both are uses of the sandal, for even he who exchanges the sandal for the money or food he is in want of, makes use of the sandal as a sandal. But not in its natural way. For it has not been made for the sake of being exchanged" (Aristotle, 1991, Book l, §9)

More than 2000 years later, in 1776, Adam Smith repeated Aristotle's distinction, this time on the level of the value of an object:

"The word value, it is to be observed, has two different meanings, and sometimes expresses the utility of some particular object, and sometimes the power of purchasing other goods which the possession of that object conveys. The one may be called 'value in use'; the other, 'value in exchange." (Smith, 1776, Book 1, § 4.13)

Marx used this source in "Das Kapital", Volume One, which begins with the following famous paragraph ${ }^{2}$ :

"The wealth of those societies in which the capitalist mode of production prevails, presents itself as 'an immense accumulation of commodities,' its unit being a single commodity. Our investigation must therefore begin with the analysis of a commodity." (Marx, 1887, v.1, ch.1, §1)

Nowadays, where we understand the economy as a social construction and are aware of the relativity of value given to objects, we are still confronted with the same distinction and also with the transition of objects adding to the attribute "use value" the property of "value in exchange". This process -in contemporary terms known as

\footnotetext{
2 [Online version]

<http://www.marxists.org/archive/marx/works/1867c1/ch01.htm> [consulted in 03/04/2009]
}

commodification ${ }^{3}$ - did not come to an end yet. Still we are witnesses of new transformation processes in which useful things enrich their essence -they become commodities by showing the twofold character of value in use and value in exchange.

\subsection{Commodification of goods and services}

History gives many examples of this process: Medieval farmers grew livestock, vegetables and fruits mainly for their own needs; their products were directly consumed by themselves or by the feudal lord. Farmers of the $21^{\text {st }}$ century produce nearly everything for the market, only a tiny fraction of their products is directly used.

But not only was the output of farming transformed into commodities. Work itself became commodified in Europe: while under the feudal mode of exploitation the labourers were chattel of the landlord who took a portion of the harvest from the peasant population under his control, and labourers were bound to the soil of their master, under capitalism labourers became separated of the means of production and were set free, free to sell their labour-power as the only commodity which was at their disposal. The commodification of work happened in the first half of the 19th century in England. It was a humiliating process for the workers. Fifty years ago Karl Polanyi described this very contradictious development in his famous book "The Great Transformation". He showed eloquently that after the active transformation of soil and money into commodities the commodification of work opened the doors for a capitalist

\footnotetext{
${ }^{3}$ The term commodification was first attested in 1975 (http://www.etymonline.com/index.php?term=commodity), in reference to art theory, still meaning the transformation of products of human creativity into goods for sale. But one should be cautious in using the term properly, because there is also another meaning of commodification in the context of software industry. David STUTZ, an experienced software developer and musician, e.g. uses the term for software production whenever there exist stable standards and modularity. Although he quoted Marx on the term commodity, he quoted him very selectively, and only on aspects of value in use. Consequently all the attributes David Stutz found essential are related to the value in use and presuppose the existence of a value in exchange (Stutz, 2004). See also (Naetar, 2005).
} 
society. After half a century of protective measures of peasant work and the introduction of a kind of minimum wage by the Speenhamland System ${ }^{4}$, a "free" labour market emerged and allowed the capitalistic system to take off in a qualitatively new way. This structure became the prototype for the liberal economic policies applied later on in many parts of the world.

Labour-power up to now is the only commodity which - under certain conditions is able to create more value in exchange than it is needed for its own reproduction. This difference is called surplus-value and is the basis of capitalist accumulation and economic growth. Later on we will come back to the precise conditions of the generation of surplus-value in an information society.

Contemporary economies of the developed world do not only produce things or objects, they produce also more and more services on an increasing scale. About 70 percent of the Gross Domestic Product stems from services. Because of the growing importance of service industries let us take a closer look on them and compare them to material goods. Material goods cannot be consumed without destroying them, but they can be stored, accumulated, transferred or resold to other people. This is not possible for services. Their usual characteristic is that they are consumed synchronously with their production. In most cases they cannot be stored, neither accumulated nor resold after consumption. There are striking examples for that: If you have spent a visit to a rock concert you

\footnotetext{
${ }^{4}$ The Speenhamland System was a method of giving relief to the poor, based on the price of bread and the number of children a man had. It further complicated the 1601 Elizabethan Poor Law because it allowed the ablebodied -those who were able to work- to draw on the poor rates. It was set up in the Berkshire village of Speen by local magistrates who held a meeting at the Pelican Inn on 6 May 1795. They felt that 'the present state of the poor law requires further assistance than has generally been given them'. A series of bad harvests had put wheat in short supply and consequently the price of bread had risen sharply. The situation was made worse by the growing population and because of the French Wars. This meant that grain could not be imported from Europe. Things were so bad that famine was a distinct possibility and there was a fear among the ruling classes that the lower orders might be tempted to emulate the French, and revolt. There had been a spate of food riots in the spring of 1795 (Bloy, 2001).
}

cannot transfer it to somebody else - the only thing one could transfer is the ticket you may have been bought in advance, giving you the right to consume the service. This right you could move to another person, but not the service itself which disappears after consumption. This does of course not mean that there is no effect induced by the consumed service. There could be many and also important effects, but they can only happen in another production or consumption process.

From now on we will deal not only with physical things but also with services, when we refer to the output of any production by human beings. Nevertheless the difference between material products on the one hand and services on the other will keep us busy throughout the paper. What the two have in common is their ability to be sold on the market. Their value for the customers is appreciated by a price linked to them.

There are lots of examples for the commodification of services in the past: The preparing of meals mostly done by women at home has partly become the service of restaurants. Caring for a child is partly replaced by Kindergartens, cleaning clothes is partly done in a laundry. The jobs very often are done by women who are now wageearners instead of offering the service for free within a personal relationship called marriage. Former amateur activities in sports or services provided by networks of friends for charity become ruled by professionalisation and thus start to be marketed.

It is worth while to mention that commodification of services is a contradictory process, it can be demeaning and dehumanising, but also liberating and progressive, giving room for social innovation by destroying traditional bounds. Also, with commodification one can see a change from personal relationships towards often anonymous market relations. The relations between people are replaced by relations between people and things.

While the above examples refer to individuals or the family, we can see another institution of the civil society, the European welfare state, as a source of commodification. More and more services it provided once for 
free are transformed into services on a "userpays" system. Education, public transport, health care, water supply, road works, which in many cases were financed out of tax revenue, have to be paid now directly by the customer. Under the current influence of neoliberalism in many cases private enterprises provide for services instead now. We call this commodification process privatisation.

Not only the family or other institutions of civil society and the state, but also private enterprises can become sources of commodification. In the last decades, the process of outsourcing has become a kind of a fashion: Accounting, placing or receiving telephone calls, transport, marketing, quality control, or even the production of some intermediary goods can be outsourced and is subsumed under the forces of the market.

Leasing of cars or machinery triggers a process of second order in commodification by exploiting the difference between the ownership of a commodity and the services provided by it. While the ownership of a car remains with the leasing firm, the services of the car are sold to the client, feeding now two markets instead of one.

But the process of commodification is no one-way-street. There are also processes of de-commodification. Former commodities can be moved into the realm of self-service: The assembling of furniture, the weaving of carpets, the baking of bread are only a few examples, where the former market for things is replaced by the marketing of the ingredients to construct, to produce or finalise the usevalue at home. It is also true for services like in the case of bank-tellers, self-service restaurants or slot-machines, where the activities of former employees are replaced by the activity of the client her/himself.

\subsection{Concepts of productivity of labour}

To understand the effect of such a transformation of goods and services towards wider areas of profitability and increased access to markets we should analyse the different concepts of productivity of labour provided in economic theory. The concept of productivity allows us to create a link between the output of an activity and the basis of it. Depending on the specific perspective economists hold, their concept of productivity can be very different. Once again we try to start from an ideal environment early in history where markets were not yet in place. It leads us to the concept of

\section{Productivity(1)}

The first meaning of productivity could be imagined as an activity done within a group, a family or a tribe where people produce and consume jointly. One could also assume that money has not yet been invented. Productivity(1) relates values in use to human labour applied. This is a kind of guarantee not to loose contact to the origin of wealth as stressed e.g. by Adam Smith. If there is a need for any good or service and there is anybody to produce it, the person creating the good or the service is a productive(1) labourer. One could measure productivity(1) by e.g. number of flintstones per year or maybe per hour, person or community. The measure itself will also inform us about the level of virtuosity the special tribe has established at a certain point in time. There are two aspects of this information. The first one deals with the quantitative measure of output which can be compared over time or between different groups, the second aspect is related to quality: What is the kind of output produced? Is the output a new one or is it a traditional one we have also seen before being produced? Productivity(1) can be measured in any society at any time, independent of the social order. The dimension of productivity(1) is a number measuring the output of a certain kind (value in use) divided by labour time.

\section{Productivity(2)}

The second meaning of productivity is related to a market society. This concept assumes the use value of the commodities as given and addresses explicitly their value in exchange as products of human labour. To establish the concept we invent an ideal economy where only one kind of a material product is produced. We assume a price system which allows buying and selling the product according to the labour time needed for its production. People should buy and sell at a price which is proportional to the labour 
time necessary for production. We assume for the sake of simplicity that all the workers have equal productivity(1) and are able to produce a surplus. As we define our economy in a way that the values in exchange are proportional to the physical amounts, measured in kilograms or tons, we make also sure that the physical surplus is proportional to the surplus value, measured in time units, or to the amount of profit accumulated, in monetary units.

But the assumption of a material product is crucial. The problem arises with the production of services. At first glance it is not clear what will happen if services are produced. Will service providers function in the same way as producers of things? While it is evident that the service providers also produce values in use, it is less clear if they also create values in exchange.

To test this case we specify our thought experiment: Let us assume there is a tribe making a living out of agriculture. Every person is working as a farmer, and they are able to create a surplus - of lets say 10 tons of wheat, being stored in a silo. This amount was created as the aggregated results of individual efforts by each of the members of society.

Now, at the beginning of the next year, let us bring into this archaic society a service provider, a shaman, a witch, a priest or a teacher, and let us monitor what will happen to the surplus. If we assume that the service provider will just increase the well-being of the members of the society, but there is no effect on productivity(1), what do you expect will be left in the silo at the end of the year? In fact, there will be less wheat than in the year before. In money terms, there will also be less monetary wealth (=profit) with each member of the tribe than before. The reason is simple: The service provider could not add to the material product of the tribe, but had to consume from this fund to stay alive without being able to compensate the society in terms of value in exchange, notwithstanding that he contributes in terms of use-value.

What is the conclusion of this thought experiment? While producers of things produce value in use AND value in exchange, service providers, while also producing values in use, cannot contribute neither to the amount of value in exchange nor to valueadded, because their contribution does not affect surplus value in a positive, but in a negative way. Instead of adding to the surplus product (proportional to surplus value and to profit), the service provider reduces it.

The conclusion therefore is that productivity(2) in a market economy depends on the kind of output. A producer of material products is productive(2), while a service provider is not. In other words one could say: A person increasing value in exchange (and surplus, surplus value and profit) by its work is productive(2), while another person not doing that is productive(1), but is tapping on the value-in-exchange produced elsewhere in the economy. Their level of productivity(2) is zero.

\section{Productivity(3)}

The third possibility of productivity is essentially linked to capitalist societies. Here we can observe that not only producers of things can make profits, but also service providers. The question remains: If service providers generate neither (physical) surplus nor surplus value (measured in labour time), where does the profit they earn come from? The answer is straightforward: If there is no other source of profit than the producers of material objects, in capitalist societies a redistribution mechanism must be in place which transfers profits from its origin to the place of appropriation. The mechanism which can do that is the system of relative prices. In short we can call a labourer productive(3) if he/she is mediating profits for his/her enterprise.

Let us summarize where we ended up with these three definitions: The first notion of productivity is related to human beings who produce values in use, the second one is linked to the production of reified values in exchange, and the third one with the attraction of profits associated to applied labour. With these distinctions in mind we are well equipped to continue now with contemporary phenomena of commodification where technological development and legal issues create a new framework. 


\section{The role of technology}

Up to now we have looked for objects which had already existed before they were sold on the market and by that process commoditized. Now let us look for new ones, emerging by invention. The ingenuity of creative persons or groups was always able to invent new objects unseen before. Good examples are the invention of the steamengine, the TV-set or the Personal Computer. In fact they were developed for the market and created large scale industries, offering jobs and promising profits.

Product innovations are new objects stimulating economic development and enlarge the realm of marketable goods. They add to the amount of value in exchange prevailing in the economy, opening up new areas of commodities where all three measures of productivity can be established.

Process innovations like the steam-engine have an additional effect: usually they are reified in any kind of machinery and thus fulfilling the attributes of product innovations, but at the same time they will increase the productivity(1) of labour for goods or services produced by these new means of production elsewhere in the economy.

Technological innovations represent the classic form of expanding the realm of commodities. But with the emergence and tremendous expansion of information technologies, the computer and the Internet, a new field of commodification emerged. Information technologies allowing now everybody to store, transfer, copy, analyze and modify information, recently more and more on a digital basis and at falling costs. The process is not a really new one. It started with the human ability of painting and writing, with the invention of the printing press, photography and film fixed on paper or celluloid, and continued with tapes and records. Recently, the potential for storing information has grown once more with Compact Disks (CD) and Digital Video Disks (DVD) where information is coded in binary.

\subsection{Reification and reanimation}

In the context of commodification we focus on technologies which might be used to store specific volatile activities on a carrier, physically or energetically. Pop or classical concerts, theatre performances, the actors posing for a movie, lectures, story tellers, but also the situation you have encountered in your holidays, the first steps of your child, are subject to reification. The carrier can be used to reanimate the activities of the past. They like in a time machine - can be moved into presence. If the recorded and stored action is requested by the public, the placement of the "frozen action" on the market for sale seems obvious if the proper replay facilities are also available. In fact, two areas of commodification are exploited by big business: There is a market for carriers of information, representing reified services, and also a market for devices to bring them to life again, to reanimate and replay the past activity. In particular this is true for software development. The code is reified in computer programs on whatever carrier you like and can be read and (re)animated by computers.

\subsection{Copying}

But reification and reanimation is only part of the potential of technology. While technology prepared the ground for commodification by creating the physical/energetic basis of a commodity, which therefore can be stored, re-sold and accumulated, it undermines the possibility of commodification at the same moment by the threat that the commodity can be copied and transferred via the Internet nearly without costs.

In such a situation free riders will show up. They will copy the content and will resell it at a lower price or - in the extreme - will give it away for free. Anyway, the market will be undermined and can no longer be used to end up with proper profits. The process of commodification is under the threat of being reverted. This situation creates opposite perspectives, depending on the interests of the persons. While the group of potential users of software and digital content will favour free riding, the management of the involved companies would like to see a situation which will enable them to sell the output at a proper price. 


\subsection{The role of the Law}

To assure this, lawyers have invented particular regulation mechanisms: copyrights, patents, licences, or generally speaking, intellectual property rights. The Law has been called for support. The laws provide people who would do copies with the threat of a fine. Even if laws cannot really make copying (technically) impossible, laws are sufficient to keep up a market for certain reified services. Under such preconditions the commodification process will be completed and will lead to the intended result: New sources of profits have emerged.

To assure the market of reified services, within the last 5 years the European Union has issued two European Directives on copyright in the information society. The "Directive 2001/29/EG on the harmonisation of certain aspects of copyright and related rights in the information society" of 22 May 2001 contains several regulations on net security, ${ }^{5}$ while the "Directive 2004/48/EC of the European Parliament and of the Council on measures and procedures to ensure the enforcement of intellectual property rights" of 29 April 2004 intends to give a copyright owner proper instruments for the realisation of his rights. ${ }^{6}$ By these directives the European Union created an obstacle of second order against illegal copying. It no longer just puts the violation of the copyrights under fine, but it protects in addition the technical means, that make copying impossible or detectable, with legal instruments. It is quite interesting to see the wording by which the Directive reflects the ambiguity of technical measures. On the one hand it enables the rightholders to apply technological measures to protect their rights, on the other it calls for a harmonised protection against technological measures to circumvent the formerly requested measures:

Technological development will allow rightholders to make use of technological measures designed to prevent or restrict

\footnotetext{
${ }^{5} 18$ months after the Directive was issued the Member States had to bring into force national legislation necessary to comply with the Directive.

6 "Member States shall bring into force the laws, regulations and administrative provisions necessary to comply with this Directive by 29 April 2006" (Directive 2004/48/EC, Art. 20, Par 1)
}

acts not authorised by the rightholders of any copyright, rights related to copyright or the sui generis right in databases. The danger, however, exists that illegal activities might be carried out in order to enable or facilitate the circumvention of the technical protection provided by these measures. In order to avoid fragmented legal approaches that could potentially hinder the functioning of the internal market, there is a need to provide for harmonised legal protection against circumvention of effective technological measures and against provision of devices and products or services to this effect. (Directive 2001/29/EG, Preamble, Par 47)

In the Directive 2004/48/EC the European Union specifies the technological measures for discs produced in the Community:

\begin{abstract}
"Monitoring of the manufacture of optical discs, particularly by means of an identification code embedded in discs produced in the Community, helps to limit infringements of intellectual property rights in this sector, which suffers from piracy on a large scale."
\end{abstract}

But even those targeted provisions could have side-effects threatening the opening of the market. Immediately after having approved the identification code for discs to keep up their exclusivity and thus allow for taking advantage of property rights, the Commission hastens to assure free trade and deregulated markets:

"However, these technical protection measures should not be misused to protect markets and prevent parallel imports". (Directive 2004/48/EC, Preamble, Par. 29).

\subsection{Claims for extended commodification}

How sensitive the issue of copyright can be, is illustrated in the following. At the time when this article was written, requests from $\mid \mathrm{FPI}^{7}$, the voice of European corporate

\footnotetext{
${ }^{7}$ IFPI (international federation of the phonographic industry) represents the recording industry worldwide with
} 
copyright holders in the performing arts, could be heard to extend the expiration date of their copyrights. Copyright terms for individual creators in the United States are awarded for the life of the author plus 70 years. U.S. companies hold copyrights for 95 years before creative works return to the public domain. Currently in the EU, there are separate copyright terms for composers and performers. Composers are awarded copyright for the life of the author plus 70 years. Performers hold a copyright for 50 years from the first recording. It's the 50-year term the IFPI wants to extend. What would be the effect if the change would pass legislation? Stanford Law School professor Lawrence Lessig (Dean, 2005) called their request "outrageous" and translated it into plain text: "They had a 50-year monopoly; they are asking for a welfare grant to say, 'Give us another 50-year monopoly.' The justification from an economic perspective is absolutely baseless." $\mathrm{He}$ compared the situation to an engineer signing a contract to build a bridge in London for $\$ 2$ million, then building a similar bridge in the United States for $\$ 4$ million -- and then after the bridges are done, demanding $\$ 4$ million for the London bridge, too. The background for this request: The issue of expanding copyright in Europe has flared up as the EU copyrights of famous rock ' $n$ ' rollers like The Beatles and Elvis are due to expire within the next several years.

The fight is not limited to copyrights in performing arts. More important is the ongoing struggle between the European Council, the European Commission and the European Patent Office on one side and the European Parliament on the other on patenting software. In 2002, the European Commission's Directorate for the Internal Market (under Monti's successor Frits Bolkestein) submitted proposal 2002/0047 for a Directive "on the patentability of computer-implemented inventions". The Directive was claimed to serve the purposes of harmonizing Member State laws and clarifying some details with the aim of preventing excesses of the European

over 1450 members in 75 countries and affiliated industry associations in 48 countries.
Patent Office (EPO) (Christofides, 2005). ${ }^{8}$ The European Parliament intends to turn down the proposal of the Commission because many MEPs are afraid of the damaging effects on innovation and competition. They expect that the directive could open up ways to patent business methods, education methods, health methods, via software patents. Members of the European Parliament prefer to keep up and enforce the existing Law which clearly prohibits patenting pure computer programs.

Contrary to an increased protection of proprietary content Lawrence Lessig, mentioned above, as an alternative founded Creative Commons ${ }^{9}$, a group that developed an internationally applicable system of flexible copyright licenses that enable sharing and remixing of creative works (with the author's permission). Creative Commons is a new system, built within current copyright law, that allows to share one's creations with others and use music, movies, images, and text online that's been marked with a Creative Commons license.

The tendency for further commodification is not only targeted at software, it also points at nature itself. Nobody would have expected that patents could be claimed for chemical elements, before 1964 thought to be part of nature. But there is the story of Glenn Seaborg, who was credited with discovering two additional elements, americium (number 95, Americium-241 is used in smoke detectors) and curium (96), on which he obtained patents in 1964, making him the only person ever to patent a chemical element (House, 1999). More recently a Harvard chemist, Charles Lieber, became holder of US-patent 5.897 .945 in the field of nanotechnology, giving him the right on exclusively manufacturing nanostructures of oxides of 33 elements, nearly a third of the oxides existing on earth. The importance of patents in this area cannot be underestimated. "Nanotechnology is everywhere and is rapidly being

\footnotetext{
${ }^{8}$ Expecting a change in European legislation the EPO has meanwhile granted more than 30,000 pure software patents in anticipation of the new legislation, and the number has recently been rising at a rate of 3,000 per year.

${ }^{9}$ Creativecommons home page, [Online] <http://creativecommons.org/> [consulted in 03/04/2009]
} 
commercialized. The quality of nanotechnology patents and licensing agreements will be significant in determining the success or failure of commercializing a nanotechnology innovation." (Featherstone, 2004) As nanotechnology will have extremely wide applications in many fields (in medicine, pharmaceuticals, mechanics, electronics), but the fundamental technologies for production are only a few ones, the outcome could be the opposite of the original intention of the patent to protect the inventor, but it could lead to monopoly (Langenbach, 2005).

\subsection{A new dimension of use values}

It seems interesting that with the development of Intellectual Property Rights a new dimension of use values comes into being. Traditionally, the use value was only seen as related to an individual. It represents a useful thing or service to a single person. After the transfer of a use value from one individual to another by selling it, the new owner of the use value could completely decide on the use of the value and had complete control over it. The selling person lost at the same time all rights on its use. The new owner could consume the commodity, could invest it, could resell it or store it as she/he liked. In contrast to this situation, the U.S. copy right allows the owner of the right to control and to restrict to a certain degree the use of the commodity even after the good was sold. European creators of information goods cannot even sell their rights ("Urheberrecht"). It remains their innate right all their life to control under what circumstances e.g. a picture or a photo can be shown in an exhibition. What they can sell to others is just the right to copy. Even if you would like to use a piece of artwork as inspiration and as a basis of your own version you cannot do so without the permission of the owner of the copyright.

This is a rather new tendency which can be seen also in other fields. The buying act does no longer mean a complete interruption of the link between any commodity and its seller. On the contrary, the selling person keeps certain rights on the use value. And there are various categories of these links possible: It can be a right like in the IPR case, but it can also be an obligation to the selling person or institution. During the recent years it has become the obligation of a seller of batteries, certain drugs, bottles, consumer electronics, refrigerators or PCs to take the devices back as waste without additional costs after they are worn out or broken. Also more and more consumer protection rights have been established in many countries. If the device does not work for a minimum period of time after it was bought, the seller has the obligation to repair it or to provide a replacement free of charge. To a certain extent one can also see laws limiting working hours, collective treaties, and ergonomic laws on workers' ill health protection as continuing links of the seller of the working power after she/he has sold her/his productive ability. In this case the Law restricts the otherwise free interplay between supply and demand in favour of the workers.

The same tendency can be seen not only on the basis of law but also by the specific design of consumer technology, e.g. if one has to keep up the link to the seller of electronic printers by buying earlier or later expensive colour or toner cartridges or to sign maintenance contracts in case of more complex machines and devices like central heating systems etc. ${ }^{10}$

All these are examples of new dependencies of positive or negative kind, depending on the point of view and the particular interest and position in the system. One could interpret them as new ways of socialization, expanding or restricting the interdependencies of human beings in the information society. It would be worthwhile to investigate these socialization tendencies in more detail elsewhere.

\footnotetext{
${ }^{10}$ Once again I am indebted to Dieter Haustein who gave this comment.
} 


\section{References}

Aristotle. (1981). Politik. Translated to German by Eugen Rolfes, Hamburg: Meiner.

Bloy, Marjie (2002) The Speenhamland System. Nagoya University (Japan): The Victorian Web. [Online] <http://www.victorianweb.org/history/poorlaw/speen.html> [consulted in 03/04/2009]

Christofides, A. (2005). Software Patents in Europe: A Short Overview. [Online] <http://eupat.ffii.org/log/intro/index.en.html> [consulted in 03/04/2009]

Dean, K. (2005). Keeping Up With Uncle Sam. [Online] Wired <http://www.wired.com/entertainment/music/news/2005/06/67783> [consulted in 03/04/2009]

Featherstone, D.J., Specht, M.D. (2004). Nanotechnology Patents: A Snapshot of Nanotechnology Patenting Through an Analysis of 10 Top Nanotech Patents. Intellectual Property \& Technology Law Journal, 16(12),1-6.

House, P. (1999), Glenn T. Seaborg, Citizen-Scholar. [Online] Seaborg Mathematics and Science Center, Northern Michigan University. < http://webb.nmu.edu/Centers/Seaborg/SiteSections/AboutUs/CitizenScholar.shtml > [consulted in 03/04/2009]

Langenbach, J. (2005). Patente auf chemische Elemente? Die Presse, 22(June), 40.

Marx, K. (1973). [orig. (1939-41) Grundrisse der Kritik der Politischen Ökonomie] translated by Nicolaus Martin, Outlines of the Critique of Political Economy, London: Penguin. [Online] (2002) Marx/Engels Internet Archive (marxists.org) <http://www.marxists.org/archive/marx/works/1857/grundrisse/> [consulted in 03/04/2009]

Marx, K. (1887). Capital. Translated by Samuel Moore and Edward Aveling, edited by Frederick Engels. [Online] (1995) Marx/Engels Internet Archive (marxists.org) <http://www.marxists.org/archive/marx/works/1867-c1/> [consulted in 03/04/2009]

Naetar, F. (2005). 'Commodification', Wertgesetz und immaterielle Arbeit. Grundrisse 14, 6-17.

O'Reilly, T. (2004). Open Source Paradigm Shift. [Online] O'Reilly Media, Inc. <http://tim.oreilly.com/articles/paradigmshift_0504.html\#swcommod> [consulted in 03/04/2009],

Smith, Adam. (1776, $4^{\text {th }}$ Ed. 1904). The Inquiry into the Nature and Causes of the Wealth of Nations. Cannan (ed.), London: Methuen \& Co [Online] Liberty Fund < http://www.econlib.org/library/Smith/smWN.html > [consulted in 03/04/2009]

Stutz, D. (2004). Some Implications of Software Commodification. [Online] <http:// www.synthesist.net/writing/commodity_software.html> [consulted in 03/04/2009]

\section{About the Author}

Peter Fleissner

Born 1944, currently Chair of both the association Transform!at, he co-founded in 2006, and the Institut für Machtforschung (since 2006), as well as member of the Emergence Of Projects (EOP). He was Head (1990-2006) of the Institute of Design and Assessment of New Technologies, at the University of Technology in Vienna, Austria. He was temporary agent for the European Union for seven years by the European Commission and the European Monitoring Centre on Racism and Xenophobia. Before 1990, he worked for the Austrian Academy of Sciences at the International Institute for Applied Systems Analysis; as research scholar at MIT (USA) and at the Institute for Advanced Studies (Austria). He has successfully managed more than 27 research projects (many of them international) and has worked as a consultant for Siemens, Munich, for ORF (Austrian Radio and Television), for the Science Center, Berlin, for the Institute for Systems Technology and Innovation Research, Karlsruhe, for the Austrian Chamber of Labour and for the Austrian Association of Industrialists.

Fleissner is an elected Member of the Leibniz-Sozietät, Berlin, and is member of the Board of Directors of the research institute of the Black Sea Economic Association (ICBSS, Greece), and of the Advisory Board of the recently founded United Nations University/College of Europe (Belgium). He has authored or edited hundreds of book chapters, articles in scientific journals and research reports. 